\title{
Consensus Statement on Mandatory Registration of Clinical Trials
}

Published online: 27 March 2007

(C) 2007 The Society for Surgery of the Alimentary Tract

The member journals of the Surgery Journal Editors Group (SJEG), in keeping with their commitment to high ethical standards and integrity in surgical publishing and surgical science, agree to adopt the position of the International Committee of Medical Journal Editors (ICMJE) ${ }^{1,2}$ requiring mandatory registration of all clinical trials, whether publicly funded or commercially sponsored, as a condition of consideration for publication. In addition, the SJEG will require registration of phase I and phase II trials.

Specifically, the SJEG supports the idea of promoting a publicly accessible clinical trial database as suggested by the World Health Organization (WHO) International Clinical Trials Registry Platform established in August 2005, which specifies 20 key study data reporting requirements ${ }^{2}$. The goal of the WHO initiative and this SJEG requirement, based on the ICMJE statement, is to promote transparency and honesty in reporting prospective clinical trial conduct and results (including negative results), to foster public trust, and to ensure that researchers behave in an ethically responsible manner toward patients and study participants ${ }^{3}$.

The SJEG member journals will require all clinical trials that prospectively assign human subjects to medical interventions, comparison groups, or control groups for the purpose of examining the potential health effects of such interventions, to be registered in one of several free, publicly accessible, nonprofit electronically searchable databases such as the one administered by the National Library of Medicine (NLM), which is located at http://www.clinical trials.gov. The ICMJE defines medical interventions as those that include, among other things, drugs, surgical procedures, devices, behavioral treatments, and processof-care changes ${ }^{2}$.

The required minimal registration data set includes a unique trial number established by the registry, funding source(s), primary researcher and public contact person, ethics committee approval, trial recruitment information, interventions and research hypotheses, and basic methodology 2,4 .

The SJEG member journals will require registration of all prospective clinical trials as of July 1, 2007. Trials that begin after July 1, 2007 must register before enrollment of the first study subject, and trials that began before the deadline must register before editorial review. Submitted manuscripts must include the unique registration number in the abstract as evidence of registration.

Authors submitting manuscripts reporting on unregistered clinical trials may request consideration of their papers if they can provide sufficient evidence of merit, although we anticipate that all clinical trials will be registered after July 1, 2007.

This statement is being simultaneously published in the respective journals of the members of the Surgery Journal Editors Group, as follows:

$\begin{array}{ll}\begin{array}{l}\text { American Journal of Surgery } \\ \text { Annals of Surgery }\end{array} & \text { Kirby I. Bland, MD } \\ & \text { Layton F. Rikkers, MD, Keith } \\ \text { D. Lillemoe, MD } & \text { Charles M. Balch. MD } \\ \text { Annals of Surgical Oncology } & \text { L. Henry Edmunds, Jr., MD } \\ \text { British Journal of Surgery } & \text { John Murie, MD } \\ \text { Canadian Journal of Surgery } & \text { Garth L. Warnock, MD, } \\ & \text { James P. Waddell, MD } \\ \text { Digestive Surgery } & \text { Markus W. Büchler, MD, } \\ & \text { John P. Neoptolemos, MD } \\ \text { Diseases of the Colon and Rectum } & \text { Robert D. Madoff, MD } \\ \text { Journal of the American College of } & \text { Timothy J. Eberlein, MD } \\ \text { Surgeons } & \\ \text { Journal of Burn Care and Research } & \text { Richard Gamelli, MD } \\ \text { Journal of Gastrointestinal Surgery } & \text { John Cameron, MD, Keith } \\ & \text { Kelly, MD } \\ \text { Journal of Laparoendoscopic \& } & \text { Mark Talamini, MD } \\ \text { Advanced Surgical Techniques } & \\ \text { Journal of Pediatric Surgery } & \text { Jay L. Grosfeld, MD } \\ \text { Journal of Pelvic Medicine and } & \text { Alfred E. Bent, MD } \\ \text { Surgery } & \\ \text { Journal of Plastic \& Reconstructive } & \text { Rod J. Rohrich, MD } \\ \text { Surgery } & \\ \text { Journal of Surgical Education } & \text { John A. Weigelt, MD } \\ \text { Journal of Surgical Research } & \text { David McFadden, MD, Wiley } \\ \text { Journal of Thoracic \& } & \text { W. Souba, MD } \\ \text { Cardiovascular Surgery } & \text { Andrew S. Wechsler, MD } \\ \text { Journal of Trauma } & \text { Basil A. Pruitt, Jr, MD } \\ & \end{array}$


Journal of Vascular Surgery

Pediatric Surgery International

Surgery

Surgery for Obesity \& Related Diseases

Surgical Endoscopy

Surgical Innovation

Surgical Laparoscopy, Endoscopy \& Percutaneous Techniques

World Journal of Surgery

Zentralblatt für Chirurgie
Jack L. Cronenwett, MD,

James M. Seeger, MD

Arnold G. Coran, MD, Prem Puri, MD

Andrew L. Warshaw, MD, Michael Sarr, MD

Harvey J. Sugerman, MD

Bruce V. MacFadyen, Jr, MD, Alfred Cuschieri, MD

Adrian Park, MD, Lee

Swanstrom, MD

Maurice E. Arregui, MD, Carol Scott-Conner, MD

John G. Hunter, MD

Hans Lippert, MD, Ulrich Hopt, MD

\section{References}

1. Clinical Trial Registration. A statement from the International Committee of Medical Journal Editors. N Engl J Med 2004;351 (12):1250-1251, September 16, http://content.nejm.org/cgi/content/ full/NEJMe048225.

2. Obligation to Register Clinical Trials. International Committee of Medical Journal Editors. Uniform Requirements for Manuscripts Submitted to Biomedical Journals: Writing and Editing for Biomedical Publication. Updated February 2006, section III.J., http://www.icmje.org/\#clin trials.

3. Mandelbaum-Schmid, J. The World Health Organization announces new standards for registration of all human medical research. WHO News Releases. 2006, http://www.who.int/mediacentre/news/ releases/2006/pr25/en/index.html.

4. Chan, A-W. Global opportunities and challenges for trial registration: Update from the WHO Registry Platform. WHO Geneva, October 2006, http://www.who.int/ictrp/Cochrane_plenary_26 Oct06.pdf. 